\title{
Policy On The Development Of The Performance Of The Bima Regency Population And Civil Registration Service Employee
}

\author{
Nur Anilawati ${ }^{1)}$, Khairul Sani ${ }^{2}$ \\ 1) Sekolah Tinggi Ilmu Social Dan Ilmu Politik (STISIP) Mbojo Bima \\ 2) STKIP Taman Siswa Bima \\ *Coresponding Author \\ Email : nuranilawati741994@gmail.com
}

\begin{abstract}
As an effort to improve the performance of employees at the Department of Population and Civil Registration, Bima Regency must diagnose all factors that can improve performance and factors that can reduce employee performance, especially by knowing the challenges and obstacles faced by employees and by the institution itself. Therefore, it is very important for the Department of Population and Civil Registration, which has a low level of performance, to be able to anticipate it by involving employees in training and comparative studies (tour study) so that they have references in improving employee performance so that the public can feel exclusively the results of the employee's performance. The method is descriptive quantitative with a population of all employees and the public who receive services then the number of samples is 30 respondents random sampling. The results are $14.15 \%$ of respondents answered very satisfied, then 43.85 percent of respondents answered satisfied, and respondents who answered quite satisfied were $42.00 \%$ and respondents who answered dissatisfied $0.00 \%$. This shows that the performance of the Department of Population and Civil Registration of Bima Regency needs to be improved, marked by the high number of respondents who answered quite satisfied, namely 42.00\%.
\end{abstract}

Keywords: Policy, Development, And Performance.

\section{INTRODUCTION}

Performance can be understood as the amount of contribution given by employees to progress and development in the workplace so that it can boost performance more intensively and optimally, optimizing authority in the areas of responsibility. The performance of the Bima Regency Population and Civil Registration Service employees can be felt when it can be done in a good way and with a broader understanding, employee performance that has been carried out with certain achievements can be assessed if it has been achieved with a percentage level and can be completed quickly and easily in accordance with the vision and mission that have been set as the locomotive in the assigned tasks.

The work environment has no significant effect on performance, where the increase or decrease in performance is not directly influenced by the work environment, a good work environment does not directly improve employee performance, because employees increase their performance not because of a good work environment but there are other factors that can improve performance (Kartono dkk, 2019). Based on Government Regulation number 30 of 2019 concerning civil servant performance appraisal article 6 that the civil servant performance management system as referred to in article 5 consists of: a) performance planning; b) implementation, performance monitoring, and performance coaching; c) performance appraisal; d) follow-up; and, e) civil servant performance information system.

In order to improve the optimal and effective performance of the Bima Regency Population and Civil Registration Service employees, time and opportunity are needed in order 
to increase public trust. Strategic and productive steps are needed that must be taken in order to improve employee performance, while the strategy that needs to be carried out by the Department of Population and Civil Registration of Bima Regency is in the form of training and technical guidance in order to provide understanding and technical ability in carrying out performance and solving problems by utilizing all sources. resources available at the institution where they work. Performance targets are a specific statement that explains the results to be achieved by whom and what to be achieved are completed, can be calculated, achievements can be observed, and can be measured. Performance targets include: performance improvement, employee development, compensation decisions, and communication skills (Sinambela, 2012). Human resource development is one aspect of human resource management. Human resource development is an important business in every organization because development activities can create quality employees so that the organization can be more advanced and developed (Nikmah, Arief, 2020).

Department of Population and Registration One of the valuable assets in an agency is human resources or employees as planners and actors of the organization. Human resources can be an invaluable asset for an organization because quality human resources will encourage creativity and sustainable new innovations in an organization so that the organization will continue to grow and achieve sustainable progress. In an organization employees have thoughts, feelings, desires, status, and educational background, age and gender.

The Population and Civil Registration Office of Bima Regency is closest to the community because it is directly related to providing services so it is necessary to have good and measurable performance power so that the achievement can be maximized, one way that needs to be done is by providing opportunities for employees in carrying out their work and responsibilities. In accordance with the proportional level of the employees themselves, in this way, the employee's ability to carry out work on time and minimize errors will be known. Competence, motivation, and work facilities have a positive effect on employee performance, work facilities are variables that have a dominant influence on employee performance (Santoso, Andrie, 2019).

In carrying out the tasks that have been given, employees need to be given good motivation so that employees feel that their existence in completing work can be fulfilled and can be a very productive step for them, the motivation given can be in the form of rewards. Moreover, in the current reform era, performance is an easy target for community groups who are dissatisfied with the performance of the Bima Regency Population and Civil Registration Service. Human resource development for employees is learning and practicing systematically to improve their current abilities and work performance and preparation for these roles and future responsibilities (Baharun, 2016).

The phenomenon that occurs at the Department of Population and Civil Registration of Bima Regency is that employee performance seems to be decreasing, this is indicated by the level of education and experience in the various trainings attended by the employee, besides the level of employee attendance is still lacking so that it can interfere systemically in work, boredom and boredom can be a problem that is considered small but has a very large impact on employee performance productivity, the lack of service counters provided so that they are less able to accommodate the needs of people who need population services. The process of developing human resources is a continuous effort in which organizations want to improve quality and develop individual skills, knowledge, and abilities according to current and future needs. The issue of the need to obtain professional human resources is expected by many organizations to be able to compete in the era of globalization (Indayani B., 2020). Meanwhile, according to Wibowo (2014) states that competence is an ability to carry out or perform a job or task based on skills and knowledge and supported by the work attitude required by the job. 
The series of problems felt above are a small part of the Department of Population and Civil Registration of Bima Regency, especially the provision of services in issuing population documents so that it is often difficult to achieve this because employees do not always understand the provision of good and correct services in accordance with standard operating procedures. SOP) the low work ethic of employees and the limited authority they have can be an adequate obstacle for these employees. The provision of services that meet the standards that have been set is indeed a part that needs to be observed. Currently, it is often felt that the minimum service quality, even though it is still far from people's expectations, is even more concerning, the community almost does not understand with certainty about the services that should be received and in accordance with standard service procedures by the government (Nurjihan, et al, 2020).

\section{RESEARCH METHODS}

The method used is descriptive quantitative, with a population of all employees and the public who receive services then the number of samples is 30 respondents who are determined by random sampling or randomly by giving questionnaires to all samples that have been determined previously by the researcher, not only that the data also obtained with the results of the documentation contained in the research locus. It is very important to collect data to support and strengthen arguments, therefore data collection is in the form of documentation as a comparison between research results and developments in the field, both previous and ongoing.

\section{RESULTS AND DISCUSSION}

\section{Employee Work Productivity}

Productivity basically includes mental attitudes/behaviors and abilities that are oriented towards continuous improvement, and have the view that today's performance must be better than yesterday's performance and tomorrow's performance must be better than today's achievement. This pattern of behavior will encourage subordinates to always try to improve their work, as a stimulus to always do good. Employees of the Department of Population and Civil Registration of Bima Regency are quite skilled in carrying out their duties. The data obtained shows that being an employee is enough to guarantee to be able to work professionally. Increasing high performance productivity and increasing professionalism in work, will always be related to performance measures or standards.

Table 1. Respondents' Answers to Employee Performance Productivity

\begin{tabular}{llcc}
\hline No & Type of Assessment & Frequency & Percentage \\
\hline $\mathbf{1}$ & Very good & 6 & $22,00 \%$ \\
$\mathbf{2}$ & Well & 15 & $50,75 \%$ \\
$\mathbf{3}$ & Pretty good & 9 & $27,25 \%$ \\
$\mathbf{4}$ & Not good & 0 & $0,00 \%$ \\
& Total & 30 & 100 \\
\hline
\end{tabular}

Source: processed questionnaire results, 2020.

Based on the answers from respondents that the level of employee productivity is $22.00 \%$ who answered very well, then respondents who answered good were $50.75 \%$, and 
respondents who answered well were $27.25 \%$, and respondents who answered not well were $0.00 \%$. It can be said that based on the high answers from respondents to one of the variables in the type of research in the table above, employee productivity needs to be increased considering that the higher percentage value is quite good than very good.

Table 2. Productivity Level of Employee Performance at the Department of Population and Civil Registration of Bima Regency

\begin{tabular}{llcc}
\hline No & Type of Assessment & Frequency & Percentage \\
\hline $\mathbf{1}$ & Very good & 20 & $20,00 \%$ \\
$\mathbf{2}$ & Well & 55 & $55,00 \%$ \\
$\mathbf{3}$ & Pretty good & 25 & $25,00 \%$ \\
$\mathbf{4}$ & Not good & 0 & $0,00 \%$ \\
& Total & 100 & 100 \\
\hline
\end{tabular}

Source: Bima Regency Population And Civil Registration Office, 2019

Based on the answers from respondents that $20.00 \%$ answered very well, then respondents who answered good were $55.00 \%$, and respondents who answered well were $25.00 \%$, and respondents who answered not well were $0.00 \%$. The low productivity of employees is motivated by various factors.

\section{Employee Competence}

A local government organization demands the existence of regional apparatus or apparatus that has the ability in relation to work so as to produce something optimal. The existence of various complaints and a sense of community dissatisfaction with the services received or provided by the government is a reflection of the inability or an indication of the poor performance of the government.

Table 3. Respondents' Answers To Employee Competence

\begin{tabular}{llcc}
\hline No & Type of Assessment & Frequency & Percentage \\
\hline $\mathbf{1}$ & Very good & 12 & $40,00 \%$ \\
$\mathbf{2}$ & Well & 17 & $55,85 \%$ \\
$\mathbf{3}$ & Pretty good & 1 & $4,15 \%$ \\
$\mathbf{4}$ & Not good & 0 & 0 \\
& Total & 30 & 100 \\
\hline
\end{tabular}

Source: processed questionnaire results, 2020.

Based on the answers from respondents that the competence of employees is $40.00 \%$ who answered very well, then respondents who answered well were $55.85 \%$, and respondents who answered well were $4.15 \%$, and respondents who answered not well were $0.00 \%$. It can be said that this is based on good employee competence and needs to be improved in order to achieve an optimal level of competence so that the wheels of government in the institution can run well. 
Table 4. Competency Level Of Service Employees At The Department Of Population and Civil Registration Of Bima Regency

\begin{tabular}{llcc}
\hline No & Type of Assessment & Frequency & Percentage \\
\hline $\mathbf{1}$ & Very good & 20 & $20,00 \%$ \\
$\mathbf{2}$ & Well & 57 & $57,00 \%$ \\
$\mathbf{3}$ & Pretty good & 23 & $23,00 \%$ \\
$\mathbf{4}$ & Not good & 0 & $0,00 \%$ \\
& Total & 100 & 100 \\
\hline
\end{tabular}

Source: Bima Regency Population And Civil Registration Office, 2019

Based on the answers from respondents that $20.00 \%$ answered very well, then respondents who answered well were $57.00 \%$, and respondents who answered well were $23.00 \%$, and respondents who answered not well were $0.00 \%$. The level of employee competence is still motivated by various factors, one of which is the level of education and experience in participating in training.

\section{Employee Work Ethic}

With a young age, of course, he still has a high work spirit, innovation, and creativity in transferring expertise in his field of work. In addition to age, it does not mean that he does not have high work spirit, innovation and creativity in transferring expertise in his field of work, but young age is synonymous with this and is reinforced with a higher percentage level compared to other age intervals.

Table 5. Respondents' Answers To Employees' Work Ethic

\begin{tabular}{llcc}
\hline No & Type of Assessment & Frequency & Percentage \\
\hline $\mathbf{1}$ & Very good & 12 & $40,00 \%$ \\
$\mathbf{2}$ & Well & 17 & $55,85 \%$ \\
$\mathbf{3}$ & Pretty good & 1 & $4,15 \%$ \\
$\mathbf{4}$ & Not good & 0 & 0 \\
& Total & 30 & 100 \\
\hline
\end{tabular}

Source: processed questionnaire results, 2020.

Based on the answers from respondents that the work ethic of employees is $73.19 \%$ who answered very well, then respondents who answered well were $23.71 \%$, and respondents who answered well were $4.00 \%$, and respondents who answered not well were $0.00 \%$. It can be said that this is based on a good and high work ethic of employees so that it needs to be maintained in order to achieve a level of employee discipline who is aware of the responsibilities carried out and the wheels of government in the institution can run well. 
Table 6. Employee Morale Level In The Department Of Population and Civil Registration Of Bima Regency

\begin{tabular}{llcc}
\hline No & Type of Assessment & Frequency & Percentage \\
\hline $\mathbf{1}$ & Very good & 60 & $60,00 \%$ \\
$\mathbf{2}$ & Well & 30 & $30,00 \%$ \\
$\mathbf{3}$ & Pretty good & 10 & $10,00 \%$ \\
$\mathbf{4}$ & Not good & 0 & $0,00 \%$ \\
& Total & 100 & 100 \\
\hline
\end{tabular}

Source: Bima Regency Population And Civil Registration Office, 2019

Based on the answers from respondents that $60.00 \%$ answered very well, then respondents who answered well were $30.00 \%$, and respondents who answered well were $10.00 \%$, and respondents who answered not well were $0.00 \%$. The level of employee morale is very high, this can be seen from the answers from respondents, and employee morale is marked by the level of attendance and employee discipline getting better and increasing.

\section{Handling Complaints From The Public}

Some of these complaints are related to service problems in population management. The service procedures that must be passed by the public who use government services are felt to be convoluted and take a long time, and it is not uncommon for people to have to come repeatedly to the Population and Civil Registration Office of Bima Regency, making it difficult for the community because it is inefficient and in the end the community becomes frustrated. reluctant to follow proper procedures.

Table 7. Respondents' Answers On The Level Of Handling Complaints From The Community

\begin{tabular}{llcc}
\hline No & Type of Assessment & Frequency & Percentage \\
\hline $\mathbf{1}$ & Very good & 6 & $24,00 \%$ \\
$\mathbf{2}$ & Well & 13 & $39,69 \%$ \\
$\mathbf{3}$ & Pretty good & 8 & $30,00 \%$ \\
$\mathbf{4}$ & Not good & 3 & $6,31 \%$ \\
& Total & 30 & 100 \\
\hline
\end{tabular}

Source: processed questionnaire results, 2020.

Based on the answers from respondents that handling complaints $24.00 \%$ who answered very well, then $39.69 \%$ of respondents who answered well, $30.00 \%$ of respondents who answered well, and $6.31 \%$ of respondents who answered not well. It can be said that based on the poor handling of complaints and the frequent complaints experienced by the community, the agency cannot handle it considering the complexity of its performance and the lack of clarity on how to handle public complaints. 
Table 8. Level Of Problem Handling In Service In The Department Of Population and Civil Registration Of Bima Regency

\begin{tabular}{llcc}
\hline No & Type of Assessment & Frequency & Percentage \\
\hline $\mathbf{1}$ & Very good & 60 & $60,00 \%$ \\
$\mathbf{2}$ & Well & 30 & $30,00 \%$ \\
$\mathbf{3}$ & Pretty good & 10 & $10,00 \%$ \\
$\mathbf{4}$ & Not good & 0 & $0,00 \%$ \\
& Total & 100 & 100 \\
\hline
\end{tabular}

Source: Bima Regency Population And Civil Registration Office, 2019

Based on the answers from the respondents that $10.00 \%$ answered very well, then the respondents who answered well were $20.00 \%$, and respondents who answered well were $45.00 \%$, and the answers of respondents who answered not well were $25.00 \%$. The high number of responses from respondents regarding handling complaints from the community indicates that the tug-of-war in handling complaints and clearly causes this symptom to be very bad.

\section{Employee Discipline Level}

Discipline is one of the benchmarks for assessing the performance of DUKCAPIL employees in carrying out their duties, especially in serving the community. An employee who has high discipline will automatically have a great sense of responsibility for the work he carries out so that they are able to position themselves as a good servant who always sets an example for the community they serve.

Table 9. Respondents' Answers to Employee Discipline

\begin{tabular}{llcc}
\hline No & Type of Assessment & Frequency & Percentage \\
\hline $\mathbf{1}$ & Very good & 13 & $45,00 \%$ \\
$\mathbf{2}$ & Well & 15 & $51,00 \%$ \\
$\mathbf{3}$ & Pretty good & 2 & $4,00 \%$ \\
$\mathbf{4}$ & Not good & 0 & $0,00 \%$ \\
& Total & 30 & 100 \\
\hline
\end{tabular}

Source: processed questionnaire results, 2020.

Based on the answers from respondents that $45.00 \%$ answered very well, then respondents who answered good were $51.00 \%$, and respondents who answered well were $4.00 \%$, and respondents who answered not well were $0.00 \%$. The high response from respondents' answers about employee discipline indicates that the presence of employees in fulfilling their responsibilities and duties is carried out by employees. 
Table 10. Respondents' answers to the level of employee discipline

\begin{tabular}{llcc}
\hline No & Type of Assessment & Frequency & Percentage \\
\hline $\mathbf{1}$ & Very good & 9 & $35,00 \%$ \\
$\mathbf{2}$ & Well & 16 & $46,00 \%$ \\
$\mathbf{3}$ & Pretty good & 6 & $28,00 \%$ \\
$\mathbf{4}$ & Not good & 0 & $0,00 \%$ \\
& Total & 100 & 100 \\
\hline
\end{tabular}

Source: Bima Regency Population And Civil Registration Office, 2019

\section{Service Accuracy}

The service procedure at the Bima Regency Population and Civil Registration Office runs quite quickly, this according to them the service procedure carried out by the Bima Regency Population and Civil Registration Office is not too burdensome for the community, the service system in this country is the Population and Civil Registration Service Bima Regency must be committed to making changes towards improving service quality with a commitment to providing excellent service to the community.

Table 11. Respondents' Answers to Service Accuracy

\begin{tabular}{llcc}
\hline No & Type of Assessment & Frequency & Percentage \\
\hline $\mathbf{1}$ & Very good & 13 & $45,00 \%$ \\
$\mathbf{2}$ & Well & 15 & $51,00 \%$ \\
$\mathbf{3}$ & Pretty good & 2 & $4,00 \%$ \\
$\mathbf{4}$ & Not good & 0 & $0,00 \%$ \\
& Total & 30 & 100 \\
\hline
\end{tabular}

Source: processed questionnaire results, 2020.

Based on the answers from respondents that $35.71 \%$ answered very well, then respondents who answered good were $46.29 \%$, and respondents who answered well were $28.00 \%$, and respondents who answered not well were $0.00 \%$. Service procedures are very important for agencies as a service locomotive in order to achieve optimal service.

Table 12. Respondents' Answers to Service Procedures

\begin{tabular}{llcc}
\hline No & Type of Assessment & Frequency & Percentage \\
\hline $\mathbf{1}$ & Very good & 9 & $35,00 \%$ \\
$\mathbf{2}$ & Well & 16 & $46,00 \%$ \\
$\mathbf{3}$ & Pretty good & 6 & $28,00 \%$ \\
$\mathbf{4}$ & Not good & 0 & $0,00 \%$ \\
& Total & 100 & 100 \\
\hline
\end{tabular}

Source: Bima Regency Population And Civil Registration Office, 2019

Based on the answers from respondents that $30.00 \%$ answered very well, then respondents who answered good were $50.00 \%$, and respondents who answered well were $20.00 \%$, and respondents who answered not well were $0.00 \%$. The high response of respondents about the accuracy of the service has shown that the main tasks have been carried out well with full responsibility. 


\section{CONCLUSION}

Employee performance, employee abilities and employee morale at the Department of Population and Civil Registration of Bima Regency, measuring the obedience of the employees of the Department of Population and Civil Registration of Bima Regency to existing regulations: imposition of service fees/tariffs, timeliness of services and procedures or service procedures. Employee performance in providing services to the community is in a fairly good category with indicators of attendance, service transparency and service results, Based on the answers from respondents that the work ethic of employees is $73.19 \%$ who answered very well, then respondents who answered well were $23.71 \%$, and respondents who answered well were $4.00 \%$, and respondents who answered not well were $0.00 \%$.

\section{REFERENCES}

Baharun, Hassan. (2016). Performance management in increasing competitive advantage in Islamic educational institutions. At-Tajdid: Journal of Tarbiyah Science, 5(2), 243-262.

Ety Kusummanningsih, 2021. EFFECT OF EMPLOYEE DEVELOPMENT ON PERFORMANCE OF YOGYAKARTA NATIONAL LAND HIGH SCHOOL EMPLOYEES (STPN). Indonesian Journal of Social Technology: p-ISSN: 2723 - 6609 e-ISSN : 2745-5254 Vol. 2, No. January 1, 2021

Indayani B. 2020. THE EFFECT OF HUMAN RESOURCES DEVELOPMENT AND WORK SPIRIT ON EMPLOYEE PERFORMANCE AT THE OFFICE OF RELIGIOUS AFFAIRS, TINAMBUNG DISTRICT, POLEWALI MANDAR REGENCY. MANDAR: Management Development and Applied Research Journal Website: http://ojs.unsulbar.ac.id/index.php/mandar Volume 2 Number 2 June 2020 Edition 63 E-ISSN: 2654-4504 P-ISSN: 2721-1436.

Nikmah Hayati, Arief Purwanto, 2020. THE IMPACT OF HUMAN RESOURCES AND PERSONALITY DEVELOPMENT ON COMPETENCE AND PERFORMANCE (Study on Employees of the Pasuruan City Environment, Hygiene and Parks Service). Journal of Management Science Volume 6, Number 2, July 2020

Nurjihan, Jeni Kamase, Zaenal Arifin, 2020. The Influence of Competence, Work Environment and Human Resources Development on Employee Performance in Services for Transferring Certificate Rights. Center of Economic Student Journal Vol. 3 No. 2 (2020) Pg. 238-257. ISSN : 2621-8186 (Online) ISSN : 2621-8194 (Print). Center for Scientific Publishing and Publications, Faculty of Economics and Business, Muslim University of Indonesia, Makassar, Indonesia

Kartono, Asnawi, and Susilawati (2019). The Influence of Work Environment and Motivation on Job Satisfaction and Its Impact on Employee Performance at the Land Office of Merangin Regency, Jambi Province. J-MAS (Journal of Management and Science), $4(1), \quad 142-155 \quad$ ISSN $2541 \quad-6243 \quad$ (Online), ISSN 2541-688X DOI 10.33087/jmas.v4i1.82. 
Email : editorijhess@gmail.com

Santoso (2019). The Influence of Competence, Motivation, and Work Facilities on Employee Performance at the National Land Office (BPN) Klaten Regency. Scientific publication of the Faculty of Economics and Business, University of National Development "Veteran" Yogyakarta.

Sinambela, Lijan Poltak. (2018). Employee Performance Measurement Theory and Implications. Yogyakarta: Graha Ilmu.

Wibowo. 2014. Performance Management. Fourth Edition. Jakarta: Rajawali Press

Government Regulation number 30 of 2019 regarding performance appraisal of civil servants

Bima Regency Population and Civil Registration Office 